
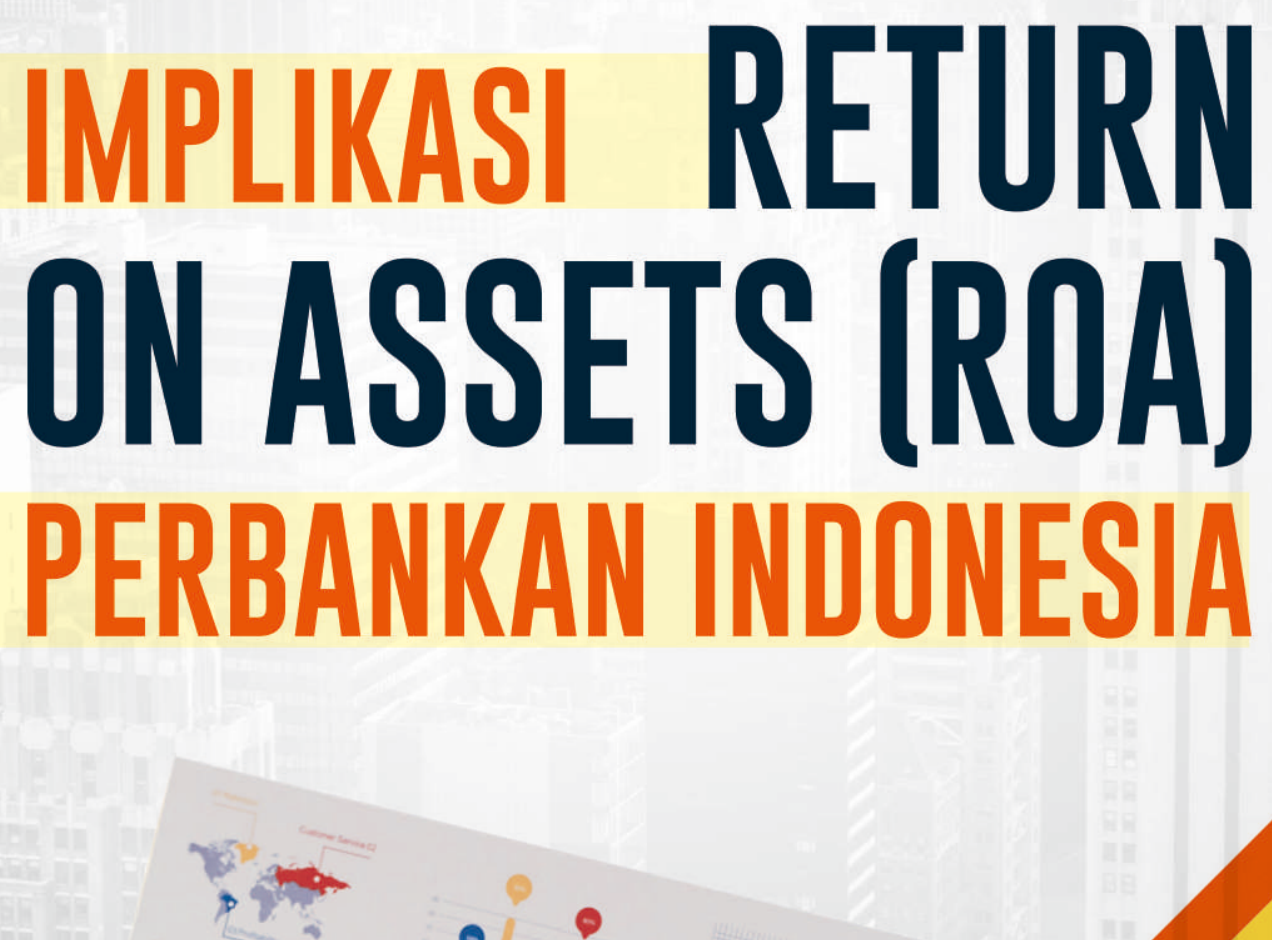


\section{IMPLIKASI RETURN ON ASSETS (ROA) PERBANKAN INDONESIA}

Maya Syafriana Effendi 


\title{
IMPLIKASI RETURN ON ASSETS (ROA) PERBANKAN INDONESIA
}

\author{
Penulis: \\ Maya Syafriana Effendi \\ ISBN : 978-623-315-618-9 \\ Editor: \\ Tri Hidayati \\ Design Cover : \\ Retnani Nur Briliant \\ Layout : \\ Nisa Falahia \\ Penerbit CV. Pena Persada \\ Redaksi : \\ Jawa Tengah \\ Email : penerbit.penapersada@gmail.com \\ Anggota IKAPI \\ All right reserved \\ Cetakan pertama : 2021
}

Jl. Gerilya No. 292 Purwokerto Selatan, Kab. Banyumas

Website : penapersada.com Phone : (0281) 7771388

Hak Cipta dilindungi oleh undang-undang. Dilarang memperbanyak karya tulis ini dalam bentuk apapun tanpa izin penerbit 


\section{KATA PENGANTAR}

Puji syukur saya panjatkan kepada Tuhan Yang Maha Esa, karena atas berkat dan rahmat-Nya, saya dapat menyelesaikan buku ini. Penulisan buku merupakan buah karya dari pemikiran penulis yang diberi judul "IMPLIKASI RETURN ON ASSETS (ROA) PERBANKAN INDONESIA". Saya menyadari bahwa tanpa bantuan dan bimbingan dari berbagai pihak sangatlah sulit bagi saya untuk menyelesaikan karya ini. Oleh karena itu, saya mengucapkan banyak terima kasih pada semua pihak yang telah membantu penyusunan buku ini. Sehingga buku ini bisa hadir di hadapan pembaca.

Kajian ini merupakan suatu pendekatan baru dengan mengkaitkan risk based bank rating yang memengaruhi penyaluran kredit dan implikasinya terhadap Return on Asset. Return on Assets (ROA) adalah indikator yang akan menunjukkan bahwa apabila rasio ini meningkat maka aktiva bank telah digunakan dengan optimal untuk memperoleh pendapatan. Return on Assets (ROA) melihat sejauh mana investasi yang telah ditanamkan mampu memberikan pengembalian keuntungan sesuai dengan yang diharapkan. Semakin besar ROA yang dimiliki, semakin efisien penggunaan aktiva sehingga akan memperbesar laba. Semakin besar Return on Assets (ROA) suatu bank semakin besar pula tingkat keuntungan yang dicapai bank tersebut dengan laba yang besar maka suatu bank dapat menyalurkan kredit lebih banyak.

Penulis menyadari bahwa buku ini masih jauh dari kesempurnaan. Oleh karena itu kritik dan saran yang membangun sangat dibutuhkan guna penyempurnaan buku ini. Akhir kata saya berharap Tuhan Yang Maha Esa berkenan membalas segala kebaikan semua pihak yang telah membantu. Semoga buku ini akan membawa manfaat bagi pengembangan ilmu ekonomi perbankan. 


\section{DAFTAR ISI}

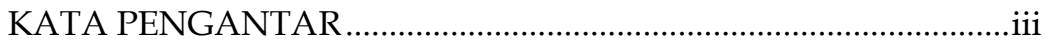

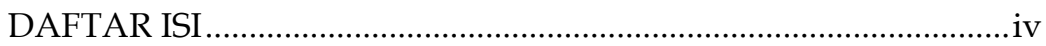

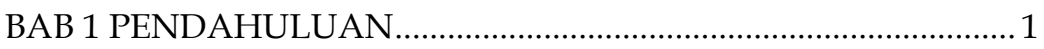

A. Pertumbuhan Ekonomi Domestik ....................................... 1

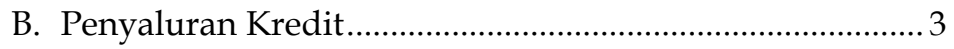

C. Kinerja Perbankan........................................................... 5

D. Return on Assets (ROA) ........................................................ 7

BAB 2 PERBANKAN, TEORI AGENSI DAN TEORI SINYAL .......12

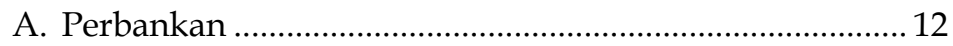

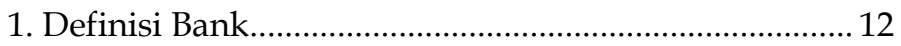

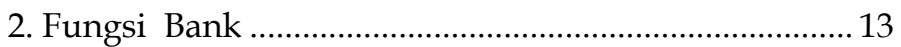

3. Penggolongan Bank ........................................................ 15

B. Teori Agensi (Agency Theory) ……………………............. 17

C. Teori Sinyal (Signalling Theory) .......................................... 22

BAB 3 KESEHATAN BANK, MODAL DAN RENTABILITAS...... 26

A. Tingkat Kesehatan Bank ……………………..................... 26

1. Pengertian Tingkat Kesehatan Bank .............................. 26

2. Profil Risiko (Risk Profile) ................................................. 29

3. Good Corporate Governance (GCG) ................................... 33

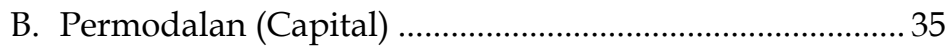

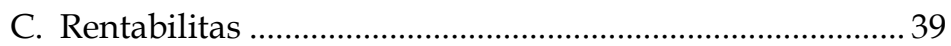

BAB 4 ANALISIS RASIO FINANSIAL \& MANAJEMEN ASET

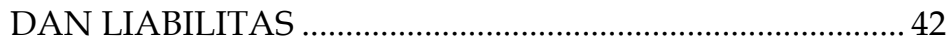

A. Analisis Rasio Finasial......................................................... 42

1. Pengertian Analisis Rasio ................................................ 42

2. Tujuan dan Kegunaan Analisis Rasio ............................ 43

B. Analisis Rasio Keuangan Menggunakan Komponen

Risk Based Bank Rating (RBBR) .......................................... 45

1. Aspek Permodalan............................................................. 45

2. Aspek Rentabilitas ........................................................... 47

3. Aspek Profil Risiko ........................................................... 48

C. Manajemen Aset dan Liabilitas (Asset Liabilities

Management: ALMA) ..................................................... 53 
BAB 5 FAKTOR - FAKTOR YANG MEMPENGARUHI ROA ......75

A. Pengaruh BOPO Terhadap ROA......................................75

B. Pengaruh CAR Terhadap ROA ...........................................

C. Pengaruh GWM Terhadap ROA ………………….............76

D. Pengaruh LDR Terhadap ROA ………………..................77

E. Pengaruh NIM Terhadap ROA …………............................

F. Pengaruh NPL Terhadap ROA …………………..............

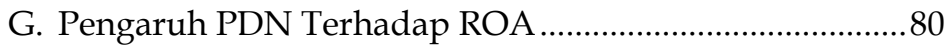

H. Pengaruh JPK Terhadap ROA ……………….......................... 80

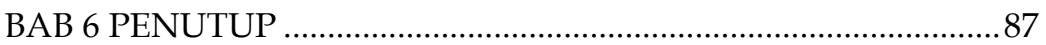

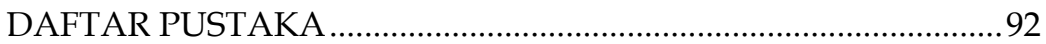

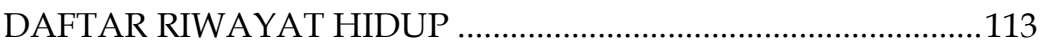




\section{IMPLIKASI RETURN ON ASSETS (ROA) PERBANKAN INDONESIA}




\section{BAB 1 \\ PENDAHULUAN}

\section{A. Pertumbuhan Ekonomi Domestik}

Perlambatan ekonomi domestik turut memengaruhi pertumbuhan kredit yang mengalami perlambatan sejalan dengan permintaan domestik yang melambat dan kenaikan suku bunga. Fungsi intermediasi perbankan tetap berjalan optimal untuk turut mendukung upaya stabilisasi untuk mendorong perekonomian bergerak ke arah yang lebih sehat, meskipun terjadi perlambatan dalam penyaluran kredit perbankan. Menurut Laporan Perekonomian Indonesia dapat dilihat pada Tabel 1.1, tahun 2013 dari Bank Indonesia, pertumbuhan kredit perbankan melambat dari 23,1\% di tahun 2012 menjadi 21,4\% pada tahun 2013. Melambatnya penyaluran kredit perbankan merupakan respon terhadap perlambatan perekonomian dan upaya dalam memitigasi potensi risiko kredit sehingga rasio kredit bermasalah Non Performing Loan (NPL) perbankan secara umum masih dapat dipertahankan yakni dibawah 5\%, pada tahun 2013 rasio NPL bruto sebesar 1,77\% lebih rendah jika dibandingkan tahun 2012 sebesar $1.87 \%$.

\section{Grafik 1.1}

Perkembangan Jumlah Penyaluran Kredit dan ROA 20 Bank Beraset Terbesar Periode 2010-2014

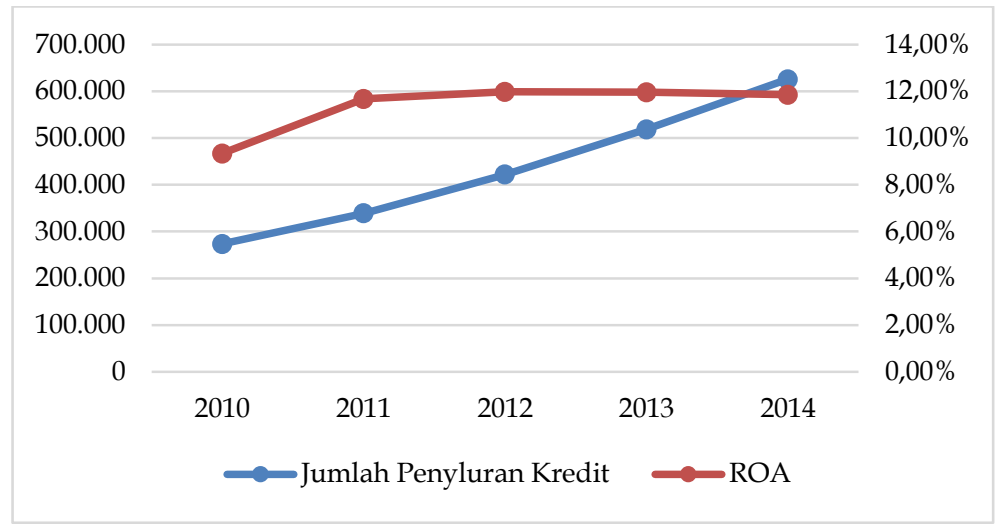




\begin{tabular}{|l|l|l|}
\hline Tahun & Jumlah Penyaluran Kredit & \multicolumn{1}{l|}{ ROA } \\
\hline 2010 & $\mathbf{2 7 3 . 2 4 5 . 0 0 0 . 0 0 0}$ & $\mathbf{9 . 3 3} \%$ \\
\cline { 2 - 3 } 2011 & $\mathbf{3 3 9 . 0 5 9 . 0 0 0 . 0 0 0}$ & $\mathbf{1 1 . 6 7 \%}$ \\
\cline { 2 - 3 } 2012 & $\mathbf{4 2 1 . 6 2 8 . 0 0 0 . 0 0 0}$ & $\mathbf{1 1 . 9 8} \%$ \\
\cline { 2 - 3 } 2013 & $\mathbf{5 1 8 , 5 0 3 . 0 0 0 . 0 0 0}$ & $\mathbf{1 1 . 9 6 \%}$ \\
\cline { 2 - 3 } 2014 & $\mathbf{6 2 5 . 3 7 2 . 0 0 0 . 0 0 0}$ & $\mathbf{1 1 . 8 5} \%$ \\
\hline
\end{tabular}

Sumber : Statistik Perbankan Indonesia 2010-2014

Grafik 1.1. menunjukkan tren perkembangan rata-rata jumlah penyaluran kredit dan return on asset (ROA) 20 bank aset terbesar yang menjadi sampel penelitian. Sejalan dengan tren perkembangan jumlah penyaluran kredit perbankan secara keseluruhan yang meningkat dengan pertumbuhan yang menurun, jumlah penyaluran kredit untuk 20 bank beraset terbesar juga mengalami kondisi yang serupa. Pertumbuhan penyaluran kredit perbankan telah mengalami penurunan dari 24,09 \% pada tahun 2011 menjadi 20,61 \% pada tahun 2014. Perlambatan pertumbuhan kredit perbankan sejalan dengan proses penyesuaian perekonomian Indonesia yang melambat, kondisi pelemahan nilai tukar serta menurunnya optimisme terhadap pertumbuhan kredit yang akan datang, sehingga berdampak pada penyaluran kredit perbankan.

Sejalan dengan penurunan pertumbuhan penyaluran kredit perbankan tidak terlalu berdampak terhadap kinerja profitabilitas. Hal ini terlihat dari return on asset (ROA) yang cenderung mengalami perkembangan yang fluktuatif dari tahun 2010 sampai tahun 2014. Pada tahun 2010 ROA perbankan sebesar 9,33\% meningkat menjadi $11,98 \%$ pada tahun 2012, kemudian mengalami penurunan pada tahun 2014 menjadi $11,85 \%$. Kondisi ini menunjukkan suatu gejala aneh, disatu sisi pertumbuhan penyaluran kredit perbankan mengalami penurunan, sementara pertumbuhan ROA berfluktuatif. Hal ini seolah-olah menunjukkan bahwa perkembangan penyaluran kredit perbankan tidak berpengaruh terhadap kinerja profitabilitas bank. 
Di tengah tren perlambatan kredit dan penurunan likuiditas, modal perbankan terus meningkat sehingga ketahanan perbankan tetap terjaga. Pada tahun 2013 (Tabel 1.2.) rasio kecukupan modal Capital Adequacy Ratio (CAR) masih tinggi sebesar $18,13 \%$ jauh di atas ketentuan minimum sebesar 8\%. Jika dibandingkan CAR pada tahun 2012 sebesar 17,43\% yaitu meningkat sebesar $0,7 \%$, hal ini mencerminkan daya tahan perbankan yang masih kuat terhadap gejolak tekanan pelemahan nilai tukar dan kenaikan suku bunga. Dari sisi profitabilitas, Return on Asset (ROA) perbankan masih cukup baik yaitu sebesar 3,08\% di tahun 2013 (Tabel 1.2. Statistik Perbankan Indonesia).

Tabel 1.2 Kinerja Bank Umum

\begin{tabular}{|c|c|c|c|c|c|}
\hline & 2013 & 2012 & 2011 & 2010 & 2009 \\
\hline Capital Adequacy Ratio (CAR) & $18.13 \%$ & $17.43 \%$ & $16.05 \%$ & $17.18 \%$ & $17.42 \%$ \\
\hline -Modal & 626,888 & 496,629 & 404,698 & 323,246 & 268,601 \\
\hline - ATMR & $3,458,404$ & $2,849,997$ & $2,520,964$ & $1,881,533$ & $1,541,598$ \\
\hline \multicolumn{6}{|l|}{ Rentabilitas (Profitabilitas) } \\
\hline Return On Assets Ratio (ROA) & $3.08 \%$ & $3.11 \%$ & $3.03 \%$ & $2.86 \%$ & $2.60 \%$ \\
\hline - Laba sebelum pajak & 134,571 & 117,103 & 95,555 & 75,157 & 61,784 \\
\hline - Rata-rata total aset & $4,365,364$ & $3,761,912$ & $3,150,826$ & $2,625,033$ & $2,372,152$ \\
\hline $\begin{array}{l}\text { Biaya Operasional/Pendapatan } \\
\text { Operasional (BOPO) }\end{array}$ & $74.08 \%$ & $74.10 \%$ & $85.42 \%$ & $86.14 \%$ & $86.63 \%$ \\
\hline -Biaya Operasional & 368,460 & 321,357 & 323,825 & 295,422 & 258,311 \\
\hline - Pendapatan Operasional & 497,384 & 433,678 & 379,120 & 342,937 & 298,180 \\
\hline Net Interest Margin Ratio (NIM) & $4.89 \%$ & $5.49 \%$ & & & \\
\hline - Pendapat an bunga bersih & 233,841 & 200,338 & & & \\
\hline - Rata-rata total aset produktif & $4,782,557$ & $3,648,741$ & & & \\
\hline \multicolumn{6}{|l|}{ Likuiditas } \\
\hline Loan to Deposits Ratio (LDR) & $89.70 \%$ & $83.58 \%$ & $78.77 \%$ & $75.21 \%$ & $72.88 \%$ \\
\hline - Kredit kepada pihak ketiga bukan bank & $3,158,099$ & $2,597,026$ & $2,117,608$ & $1,710,677$ & $1,437,930$ \\
\hline -Dana Pihak Ketiga & $3,520,616$ & $3,107,385$ & $2,688,364$ & $2,274,489$ & $1,973,042$ \\
\hline
\end{tabular}

Sumber: Statistik Perbankan Indonesia Januari 2014, Januari 2013 dan Januari 2012

\section{B. Penyaluran Kredit}

Peranan industri perbankan dalam menunjang perekonomian dapat dilaksanakan dengan cara menghimpun dana dan menyalurkannya kembali dalam bentuk kredit, dan 
atau dengan cara memperlancar pembayaran transaksi perdagangan domestik maupun internasional, sehingga bank telah berfungsi sebagai perantara keuangan (financial intermediaries) yang menghubungkan dana-dana yang dimiliki dari unit ekonomi yang surplus kepada unit ekonomi yang membutuhkan bantuan dana (deficit), baik untuk tujuan konsumsi, investasi dan modal kerja. Dalam perkembangannya, bank juga memberikan jasa dan pelayanan dalam lalu lintas pembayaran, seperti jasa penyimpanan uang, jasa pengiriman uang serta permintaan dan penawaran kredit. Penyaluran kredit merupakan aktivitas bank yang paling utama dalam menghasilkan keuntungan, namun risiko bank yang terbesar juga bersumber dari penyaluran kredit. Danadana yang dihimpun dari masyarakat mencapai 80\% - 90\% dari keseluruhan dana yang dikelola oleh bank dan kegiatan perkreditan mencapai 70\%-80\% dari kegiatan usaha bank Dendawijaya (2005). Pengertian kredit menurut Ikatan Akuntan Indonesia (Standar Akuntansi Keuangan, 2009) adalah peminjaman uang atau tagihan yang dapat dipersamakan dengan itu berdasarkan persetujuan atau kesepakatan pinjam meminjam antara bank dan pihak lain yang mewajibkan pihak peminjam untuk melunasi utangnya setelah jangka waktu tertentu dengan jumlah bunga, imbalan atau pembagian hasil keuntungan.

Penyaluran kredit perbankan memungkinkan masyarakat melakukan kegiatan investasi, distribusi dan konsumsi yang selalu berkaitan dengan penggunaan uang. Dengan lancarannya kegiatan investasi, distribusi dan konsumsi sehingga menggerakkan pembangunan perekonomian masyarakat, melalui fungsi ini bank berperan sebagai agent of development (Susilo, Triandu dan Santoso, 2006). Meskipun penyaluran kredit memegang peranan yang sangat penting bagi pertumbuhan ekonomi, namun kredit yang disalurkan oleh perbankan pada beberapa tahun terakhir belum optimal, hal tersebut dapat dilihat dari loan to deporit ratio (LDR) Bank Umum pada periode 2009-2012 berkisar 
antara $72,88 \%-83,58 \%$, masih berada di bawah ketentuan Bank Indonesia sebesar 85 \%-110\% (Manurung dan Rahardja, 2004), hanya di tahun 2013 yang memenuhi ketentuan Bank Indonesia tersebut yaitu sebesar 89,70\%. Semakin tinggi LDR menunjukkan semakin besar DPK yang dipergunakan untuk penyaluran kredit perbankan, sehingga bank telah mampu menjalankan fungsi intermediasinya dengan baik, namun LDR yang terlampau tinggi juga dapat menimbulkan risiko likuiditas bagi bank.

\section{Kinerja Perbankan}

Kinerja bank yang baik akan dapat menyokong pertumbuhan ekonomi karena peran bank sebagai penyedia dana investasi dan modal kerja bagi unit-unit bisnis sehingga mampu menggerakkan perekonomian. Oleh sebab itu bank harus bisa menjaga tingkat kesehatannya karena bank yang sehat adalah bank yang dapat menjalankan fungsinya dengan baik sehingga dapat memberikan pelayanan kepada masyarakat dan bermanfaat bagi perekonomian.

Kinerja perbankan yang meningkat didukung dengan tingkat kesehatan yang tetap terjaga sehingga dapat menyerap peningkatan risiko-risiko, terutama potensi peningkatan risiko kredit yang perlu dimitigasi dengan baik. Tingkat kesehatan bank dapat dinilai dari beberapa indikator, antara lain adalah laporan keuangan bank untuk kemudian dihitung rasio keuangan sebagai dasar penilaian tingkat kesehatan bank. Rasio dapat menggambarkan hubungan antara suatu jumlah tertentu dengan jumlah yang lain. Penggunaan alat analisis berupa rasio dapat menjelaskan atau memberikan gambaran kepada penganalisa tentang baik buruknya kondisi suatu bank. Sehingga pengukuran rasio keuangan merupakan hal yang penting sehingga dapat digunakan oleh manajemen dan investor dalam pengambilan keputusan.

Bank Indonesia sebagai regulator menetapkan Peraturan Bank Indonesia Nomor 13/1/PBI/ 2011 (Bank Indonesia, 2011) tanggal 5 Januari 2011 perihal Sistem Penilaian Tingkat Kesehatan Bank Umum (Lembaga Negara Republik Indonesia 
tahun 2011 No. 1, tambahan Lembaran Negara No. 5184) tentang Penilaian Tingkat Kesehatan Bank Umum, pedoman perhitungan tingkat kesehatan bank umum secara lengkap diatur dalam Surat Edaran Bank Indonesia No. 13/24/DPNP tanggal 25 Oktober 2011 (Bank Indonesia, 2011), yang mewajibkan bank untuk melakukan penilaian sendiri (self assessment) menggunakan pendekatan risiko (Risk Based Bank Rating/ RBBR) yang meliputi faktor-faktor: Profil Risiko (Risk Profile), Good Corporate Governance, Rentabilitas (Earning) dan Permodalan (Capital). Tingkat kesehatan bank merupakan kepentingan pihak yang terkait, baik pemilik, pengelola bank, masyarakat pengguna jasa Bank maupun Bank Indonesia dan Otoritas Jasa Keuangan sebagai pembina dan pengawas perbankan sehingga kesehatan perbankan Indonesia dapat terus ditingkatkan dalam menyokong perekonomian bangsa.

Dari tabel 1.2. di atas dapat dilihat bank umum dari tahun ke tahun dapat mempertahankan kinerjanya tercermin antara lain rasio kecukupan modal (CAR) pada tahun 2012 sebesar 17,43\% dan tahun 2013 sebesar 18,13\% di atas ketentuan minimal sebesar $8 \%$ ditahun. Rasio ROA tetap stabil di tahun 2012 sebesar 3,11\% dan tahun 2013 sebesar 3,08\%, rasio tersebut berada di atas $1.25 \%$ yang dikategorikan cukup memadai oleh Bank Indonesia. Indikator likuiditas bank umum dapat dilihat dari rasio LDR di tahun 2012 sebesar 83,58\% meningkat di tahun 2013 sebesar $89.70 \%$ berada di atas batas bawah LDR yang ditetapkan oleh Bank Indonesia yaitu sebesar $78 \%$.

Perilaku penawaran kredit perbankan juga dipengaruhi oleh faktor internal lain yaitu loan to deposit ratio (LDR) yang menggambarkan kemampuan bank dalam membayar kembali penarikan dana oleh deposan dengan menggandalkan kredit yang diberikan sebagai sumber likuiditasnya seperti yang dikemukakan oleh Suindrawati (2014) sehingga LDR dianggap berpengaruh terhadap penyaluran kredit. Menurut Suindrawati dan Aisyah (2014) dan Danistyo (2009) LDR berpengaruh signifikan dalam penyaluran kredit. 
Pemberian kredit yang dilakukan oleh bank kepada masyarakat mengandung risiko berupa ketidaklancaran pembayaran yang dapat mempengaruhi kinerja bank yang disebut dengan kredit macet atau non performing loan. NPL mencerminkan risiko kredit sehingga semakin tinggi tingkat NPL maka semakin besar risiko kredit yang akan ditanggung oleh bank (Ali, 2004). Bank Indonesia telah menetapkan rasio untuk NPL maksimal sebesar 5\%, sehingga semakin tinggi rasio NPL dapat menyebabkan dana yang disalurkan melalui kredit akan semakin berkurang karena bank wajib membentuk cadangan kerugian penurunan nilai (CKPN) yang lebih besar. Besarnya NPL menjadi salah satu penyebab perbankan sulit untuk menyalurkan kreditnya (Sentausa, 2009). Menurut Danistyo (2009) NPL berpengaruh negatif signifikan, sedangkan menurut Suindrawati dan Aisyah (2014), Trimulyanti (2013) dan Pratama (2010) NPL tidak signifikan berpengaruh pada penyaluran kredit.

\section{Return on Assets (ROA)}

Dalam mengukur tingkat kemampuan bank dalam memperoleh keuntungan yang dihasilkan dari rata-rata total asset bank maka digunakan rasio Return on Assets (ROA). ROA adalah indikator yang menunjukkan bahwa jika rasio ROA meningkat maka aktiva bank telah digunakan secara optimal untuk memperoleh pendapatan. Semakin besar ROA maka semakin besar pula keuntungan yang dihasilkan oleh bank dalam memperoleh laba maka bank dapat menyalurkan kredit lebih banyak. Menurut Trimulyanti (2013), ROA berpengaruh signifikan terhadap penyaluran kredit perbankan. Sedangkan menurut Pratama (2010), Mukhlis (2011), Saryadi (2011) dan Rosana (2012) ROA berpengaruh negatif signifikan, hal tersebut berbeda dengan hasil penelitian Budiawan(2008), Satria (2010) yang menyatakan bahwa ROA tidak berpengaruh signifikan terhadap penyaluran kredit.

Sementara tingkat efisiensi kinerja operasional diukur menggunakan rasio beban operasional terhadap pendapatan operasional (BOPO). Semakin kecil rasio BOPO maka bank 
semakin efisien dalam menggunakan biaya untuk menghasilkan pendapatan. Menurut Satria (2010) BOPO tidak signifikan berpengaruh dalam penyaluran kredit.

Rasio Giro Wajib Minimum (GWM) merupakan salah satu komponen moneter dalam mengatur likuiditas perbankan, yang merupakan perbandingan antara saldo giro bank yang wajib ditempatkan di Bank Indonesia ditambah cadangan minimum yang wajib dipelihara oleh bank berupa SBI, SUN dan/atau excess reserve dibandingkan dengan total dana pihak ketiga. Menurut Utari et al (2012) dan Gunadi dan Harun (2011) GWM berdampak signifikan, sedangkan menurut Okamoto (2011) jumlah kredit negatif signifikan dalam mempengaruhi reserve requirement.

Rasio net interest margin (NIM) digunakan untuk mengukur kemampuan bank dalam mengelola asset produktifnya untuk menghasilkan pendapatan bunga bersih, dimana pendapatan bunga bersih diperoleh dari pendapatan bunga dikurangi dengan beban bunga. Semakin besar rasio NIM maka pendapatan bunga atas aktiva produktif juga semakin meningkat.

Rasio Posisi Devisa Neto (PDN) digunakan untuk mengendalikan posisi pengelolaan valuta asing karena fluktuasi perubahan kurs yang sulit diprediksi sehingga pengelolaan dilakukan dengan pembatasan posisi keseluruhan dari masing-masing valuta asing untuk memenuhi kewajiban dalam valuta asing dan memperoleh pendapatan dari selisih kurs jual dan beli.

Hasil akhir dari kegiatan operasional yang dijalankan oleh bank adalah mencapai keuntungan yang maksimal yang ditunjukan dengan tingginya profitabilitas bank yang diperoleh. Profitabilitas merupakan suatu kemampuan bank untuk menghasilkan suatu laba secara efektif dan efisien. Menurut Sartono (2008:113), yaitu : "Profitabilitas adalah kemampuan perusahaan memperoleh laba dalam hubungan dengan penjualan, total aktiva maupun modal sendiri". 
Dari pengertian di atas, profitabilitas merupakan kemampuan perusahaan untuk menghasilkan laba dengan memanfaatkan aset yang dimiliki. Profitabilitas merupakan indikator utama untuk menilai suatu kinerja bank. Setiap bank umum memiliki tujuan yang sama, yaitu memiliki profitabilitas yang tinggi dan mendapatkan keuntungan yang layak. Dalam memperhitungkan profitabilitas dapat menggunakan rasio ROA (Return On Assets) karena ROA dapat mengukur kemampuan manajemen dalam mencapai profitabilitas serta dapat mengukur efisiensi secara keseluruhan.

Pengaruh intensifitas pemberian kredit konsumsi itu sendiri terhadap profitabilitas adalah dengan mendapatkan keuntungan dari bunga kredit yang dibebankan kepada debitur. Seperti halnya yang dikemukakan oleh Firdaus dan Ariyanti (2011:7) “Manfaat dari pemberian kredit adalah memperoleh pendapatan berupa bunga yang diterima dari debitur. Dengan diperolehnya pendapatan bunga kredit, maka diharapkan rentabilitas bank akan membaik yang tercermin dalam perolehan laba yang meningkat."

Sedangkan Mahrinasari (2003) menyatakan bahwa : "Secara prakmatis dan konsep teori lainnya jelas menunjukkan bahwa jika kredit dialokasikan besar maka tingkat likuiditas akan berkorelasi atau berpengaruh secara negatif, sedangkan sebaliknya besarnya kredit justru memperbesar tingkat rentabilitas."

Rosidah dan Muslifah (2009) menyatakan bahwa : "Secara konseptual tentunya penyaluran kredit berpengaruh terhadap profitabilitas dengan arah positif, karena semakin besar penyaluran kredit maka semakin besar pula laba yang akan dihasilkan atas penyaluran tersebut dan akan semakin membaik yang akan menyebabkan naiknya nilai return on asset namun hal tersebut juga tidak terlepas akan adanya suatu kondisi non performing loan atau kredit bermasalah yang akan mempengaruhi profitabilitas suatu bank." 
Maka, semakin tingginya volume kredit konsumsi yang diberikan, semakin besar pula suatu bank untuk mendapatkan laba atau profit yang kemudian akan mencapai profitabilitas yang maksimum sesuai dengan tujuan bank untuk memperoleh laba yang optimal. Sehingga semakin tinggi intensifitas pemberian kredit konsumsi, maka semakin tinggi bank mendapatkan keuntungan yang diperoleh dari bunga kredit yang dibebankan (Natalina, 2012).

Hasil penelitian yang dilakukan oleh Rosidah dan Muslifah (2009) mendapatkan hasil bahwa penyaluran kredit berpengaruh tidak signifikan terhadap profitabilitas. Sedangkan pengaruh Non Performing Loan terhadap profitabilitas adalah bank akan kehilangan kesempatan untuk mendapatkan keuntungan dari bunga yang seharusnya dapat diterima apabila pengembalian dana tersebut terselesaikan dengan lancar. Seperti halnya dikemukakan oleh Sutoyo (2008:25):

"Sebuah bank yang dirongrong oleh kredit bermasalah atau Non Perfoming Loan dalam jumlah besar cenderung menurun profitabilitasnya. Return On Assets (ROA) yaitu salah satu tolak ukur profitabilitas akan menurun dengan akibat nilai kesehatan operasi di masyarakat dan di dunia perbankan pada khususnya akan ikut menurun."

Hal ini sesuai dengan yang dikemukakan oleh Dendawijaya (2005:83) bahwa : “Implikasi dari kredit bermasalah adalah Return on Assets (ROA) mengalami penurunan."

Dari pernyataan diatas disimpulkan bahwa Non Performing Loan berpengaruh terhadap Return on Assets (ROA) yang dapat memengaruhi kesehatan bank dan hilangnya kesempatan bank untuk mendapatkan keuntungan atau pendapatan dari kredit yang diberikan sehingga secara langsung memengaruhi profitabilitas suatu bank. Penelitian yang dilakukan oleh Mawardi (2005) mendapatkan hasil bahwa secara parsial non performing loan menunujukan pengaruh 
negatif Non Performing Loan (NPL) terhadap perubahan laba, semakin tinggi Non Performing Loan (NPL) maka semakin besar risiko yang disalurkan bank sehingga semakin rendah pendapatan sehingga laba yang diproksikan dengan Return On Asset (ROA) menurun. Sedangkan penelitian Arimi dan Mahfud (2012), yang mendapatkan hasil bahwa secara parsial non performing loan tidak berpengaruh terhadap profitabilitas. 


\section{BAB 2 \\ PERBANKAN, TEORI AGENSI DAN TEORI SINYAL}

\section{A. Perbankan}

\section{Definisi Bank}

Bank merupakan lembaga keuangan yang bertujuan untuk meningkatkan taraf hidup masyarakat, namun sebagai badan usaha bank juga bertujuan untuk mendapatkan keuntungan. Tugas pokok dari suatu bank yaitu menghimpun dana dan menyalurkannya kembali kepada masyarakat. Dalam pengelolaan perbankan, pemerintah memberlakukan undang-undang No. 10 tahun 1998 yang merupakan penyempurnaan dari UndangUndang No. 7 tahun 1992 yang berisi mengenai peraturanperaturan perbankan yang memberikan ketegasan mengenai perbankan.

Pengertian bank menurut Undang-Undang No.10 Tahun 1998 yang dikutip oleh Kasmir (2010: 13) dan Supramono (2009:45) yaitu : "Bank adalah Badan Usaha yang menghimpun dana dari masyarakat dalam bentuk simpanan dan menyalurkan pada masyarakat dalam bentuk kredit dan bentuk-bentuk lainnya dalam rangka meningkatkan taraf hidup rakyat banyak".

Dilihat dari definisi tersebut bank berfungsi sebagai penghimpun dan penyalur dana dari masyarakat. Berdasarkan Undang-Undang perbankan No. 10 tahun 1998, bank dibagi menjadi dua prinsip yaitu prinsip syariah dan prinsip konvensional. Peran bank syariah dan konvensioal pada dasarnya adalah sama yaitu penghimpun dan penyalur dana. Perbedaan diantara dua prinsip itu terletak pada cara mendapatkan keuntungannya. Prinsip konvensional mendapatkan penghasilan dari bunga, sedangkan untuk prinsip syariah memperoleh laba dengan sistem bagi hasil (profit and loss sharing) yang melandasi kegiatan operasionalnya. Selain itu, pada bank syariah 
penyaluran dana disebut dengan pembiayaan (financing), sedangkan untuk bank konvensional yaitu kredit (loan).

Bank dalam melakukan kegiatan operasionalnya diatur oleh Undang-undang (UU) No.7 tahun 1992 tentang Perbankan sebagaimana telah diubah dengan UU No.10 tahun 1998 tentang Perbankan (UU Perbankan) dan peraturan-peraturan pelaksanaan yang diatur oleh Bank Indonesia dan Otoritas Jasa Keuangan (OJK) selaku regulator perbankan. Menurut UU No.7 tahun 1992, definisi bank adalah badan usaha yang menghimpun dana dari masyarakat dalam bentuk simpanan dan menyalurkannya kepada masyarakat dalam bentuk kredit dan atau bentukbentuk lainnya dalam rangka meningkatkan taraf hidup rakyat banyak.

Selain definisi bank di atas, beberapa definisi menurut UU Perbankan yang terkait dengan kajian ini adalah sebagai berikut:

a. Perbankan adalah segala sesuatu yang menyangkut tentang bank, mencakup kelembagaan, kegiatan usaha, serta cara dan proses dalam melaksanakan kegiatan usahanya.

b. Bank Umum adalah bank yang melaksanakan kegiatan usaha secara konvensional dan atau berdasarkan prinsipprinsip syariah yang dalam kegiatannya memberikan jasa dalam lalu lintas pembayaran.

\section{Fungsi Bank}

Fungsi utama bank secara umum adalah melakukan penghimpunan dana dari masyarakat dan menyalurkannya kembali kepada masyarakat untuk berbagai tujuan atau sebagai perantara keuangan atau financial intermediary. Secara spesifik bank dapat berfungsi sebagai agent of trust, agent of development, dan agent of services. Sebagai lembaga keuangan, peran bank sangat mendukung kemajuan lalu lintas pembayaran, perdagangan dan pembangunan ekonomi. Peran bank adalah mengumpulkan dana melalui 